\title{
INTRODUCTION
}

\section{Democracy without Shortcuts: Introduction to the Special Issue}

\author{
Nicole Curato*, Julien Vrydagh ${ }^{\dagger}$ and André Bächtiger ${ }^{\ddagger}$
}

This special issue uses Cristina Lafont's latest book Democracy without Shortcuts to stimulate a focused debate about the role of minipublics in democratic systems and the normative and practical prospects of a participatory deliberative democracy. This Editorial Introduction provides an overview of current and emerging debates on minipublics research, locates Lafont's work in these debates, and presents a summary of contributions in the issue.

Keywords: Deliberative democracy; participatory deliberative democracy; blind deference; minipublics; normative theory

\section{Introduction}

The growing enthusiasm for deliberative minipublics is one of the most important developments in democratic reform in the past decade. What used to be dismissed as a pipe dream devoid of any real-world application, deliberative democracy has demonstrated how citizen forums can be designed to uphold deliberative norms. Just this year, we have witnessed 150 randomly selected citizens deliberate across seven weekends to determine how France can cut its carbon emissions by 2030 . No less than President Emmanuel Macron called for this citizens' assembly in response to the gilet jaunes protests. Across the Atlantic, deliberations about a post-COVID-19 world have taken place in Oregon over Zoom. Meanwhile, in Tokyo, citizen deliberation meetings (shimin tougikai) are convened to empower citizens to solve everyday problems like garbage collection and congested public transport. The OECD (2020) calls this the 'deliberative wave' - a surge in the use of citizens' assemblies, juries, and panels at all levels of government, in different parts of the world.

These are significant developments. An early critique against deliberative democracy has been its failure to specify how its normative ideals can be translated in institutional terms. Liberal democracy has representative institutions of the parliament and responsible party systems. Participatory democracy has instruments like referendums, plebiscites, and citizen initiatives. What about deliberative democracy? Minipublics, one could argue, have filled this void. Talks about institutionalizing deliberative democracy often results in talks about

\footnotetext{
* University of Canberra, AU

+ Vrije Universiteit Brussel and UCLouvain, BE

₹ Universität Stuttgart, DE

Corresponding author: Julien Vrydagh (julien.vrydagh@vub.be)
}

institutionalizing minipublics. ${ }^{1}$ There has been a lot of enthusiasm with the Ostbelgien Modell (Niessen \& Reuchamps 2019) as well as the Deliberative Citizens' Commissions in the Brussels' Regional Parliament (Reuchamps 2020) for they exemplify how randomly selected citizens can shape political processes alongside members of the parliament. These examples, among others, are related to a normative vision of institutionalising a 'legislature by lot' - a sortition chamber composed of lay citizens paired with a chamber of elected representatives (Gastil \& Wright 2019; also see Sintomer 2018) - or even the 'end of politicians' which would be replaced by a representative network of ordinary citizens (Hennig 2017; Van Reybrouck 2016).

This special issue is prompted by the dizzying speed of these developments. We tip our hats to the creativity and ambition of those who aspire for a greater role for ordinary citizens deliberating about complex political issues. But we also think it is important to take a step back and pay close attention to key debates about the role of minipublics in democratic societies. How much power should we give minipublics? To what extent should we defer to decisions of an unelected, randomly selected group of ordinary citizens? How can minipublics contribute to a defensible vision of deliberative democracy today? By thinking about these questions, we hope we can be better equipped to assess the democratic quality of minipublics and spot their counter-democratic tendencies. We see this special issue as the Journal of Deliberative Democracy's contribution to on-going conversations about the institutional form deliberative democracy should take in our complex and fragile societies.

Our approach in answering these questions is to focus our discussion on Cristina Lafont's book, Democracy without Shortcuts (2019). Building on her widely cited piece 'Deliberation, Participation, and Democratic Legitimacy: 
Should deliberative minipublics shape public policy?' published in the Journal of Political Philosophy (2015), her book, in our view, offers one of the most radical yet sympathetic critiques of minipublics. It is radical because her critique challenges us to re-evaluate the normative and practical claims of minipublics research. But her work is also a sympathetic defence of minipublics by offering a concrete vision of a participatory deliberative democracy. This, we find, is a much-needed provocation at a time when many view democracies as a game of tradeoffs where its advocates are forced to choose between political equality, deliberation, and mass participation. James Fishkin (2011) refers to this as a trilemma, where focusing on two principles necessarily undermines one. Lafont's work critiques this trilemma, and, ultimately, presents a bolder vision of deliberative democracy. It is such proposition that we consider to be a valuable subject of debate today.

The special issue is composed of 10 articles responding to various sections of the book. The line-up is a combination of theoretical and empirical pieces that affirm, challenge, and extend Lafont's work. Our aim in anchoring this special issue on Lafont's work is to facilitate a focused debate about the role of minipublics in democratic systems, and to critically examine Lafont's aspiration of building a participatory deliberative democracy.

In this introduction, we provide a summary of Lafont's arguments and argue that her work signals the third generation of minipublics thinking which sets the agenda for deliberative scholarship in the years to come. We then offer short summaries of articles in the special issue weave them thematically, and conclude with several conjectures on the future of minipublic research.

\section{Open questions on minipublics}

Criticisms of minipublics often take a participatory or a deliberative perspective. The participatory critique, most forcefully articulated by Carole Pateman (2012) is concerned about how minipublics have largely ignored the institutional background in which these forums take place. For Pateman, minipublics fail to 'disturb existing institutions' and, at times, serve as 'legitimising devices for an already-decided policy' (Pateman 2012: 15). With around a third of minipublics' proposals congruent with subsequent laws and public policies (Font et al. 2018; Pogrebinschi \& Ryan 2018), it appears that minipublics have policy effects when their recommendations are congruent with decision-makers' initial preferences (Vrydagh 2019). Moreover, Lafont is sceptical of injecting minipublics' considered recommendations into a highly defective deliberative system (Lafont 2019: 135) in which 'all institutional constraints return in full force' (Hoppe 2011: 179). It remains an open question how the ideals of mass participation, redistribution of power and selfgovernment can be realised. She reminds us that the expansion of forums for deliberative participation does not always lead to 'the democratisation and the creation of participatory society' (Pateman 2012: 15, 9, 8). This is a worthy reminder especially today that deliberative forums can serve as smokescreens for more insidious forms of power and control (Curato, Hammond \& Min 2019).

Meanwhile, within the field of deliberative democracy, minipublics are critiqued for its narrow focus. It has been more than 10 years since Simone Chambers (2009) called out the 'growing split' between theories of 'democratic deliberation' which focuses on minipublics and 'deliberative democracy' which investigates the relationship between the public and the state. Like Pateman, Chambers is concerned with addressing the pathologies in today's public sphere so they can 'compliment, or at least not undermine' the democratic achievements of micro-deliberative forums (Chambers 2009: 331). Marit Hammond (2019) takes the deliberative critique a step further. She rejects the controlling characteristics of minipublics which orchestrate citizens to behave a certain way through the design of deliberative forums. For Hammond, minipublics have a tendency of treating a randomly selected group of citizens as 'subjects' or 'takers' of deliberative norms instead of capable and autonomous agents who can develop selfdriven reflections. Hammond makes a compelling case for 'activist deliberative democracy' by reminding us of the field's roots in critical theory. She argues that deliberative democracy should facilitate and inspire emancipation. Its success is not built on the achievements of democratic innovations but the extent to which deliberative democracy can challenge illegitimate authority.

We situate Lafont's book in relation to these critiques against minipublics. What her work offers is a bridge between the participatory and deliberative perspectives by placing the principle of self-government at the heart of her philosophical account. 'All citizens,' Lafont argues, should 'equally own and identify with the institutions, laws, and policies to which they are subject' (Lafont 2019: 3). To achieve this aim, political systems must empower citizens to exert democratic control or the alignment of policies and considered public opinions of the whole citizenry. Do minipublics promote the principle of selfgovernment and democratic control? Hardly. Minipublics today mostly serve to align the policies and considered opinions of a microcosm of society in a bounded forum. Consequently, the whole citizenry can neither endorse the policy nor identify with its creation because they were not part of the process of authoring these policies. 'It does not appear that the public as a whole knows much about them,' as Pateman puts it (Pateman 2012: 9; also see Rummens 2016). Lafont's work speaks to the participatory critique in that empowering the few to deliberate must not be conflated to the democratisation of the wider society. Minipublics may even pose counter-democratic tendencies when the asymmetrical power relationship between citizens and elected political elites is simply replaced by a new asymmetrical relationship between the citizenry and randomly selected elites. This risks minipublics further alienating wider publics from their democratic systems.

What then is the way forward? One way forward lies in Lafont's proposition of a participatory deliberative 
democracy, which reconciles a participatory approach with the demand for shortcuts in our complex governance systems (Warren \& Gastil 2015; Warren, this issue; Bächtiger \& Goldberg, this issue). This proposition, we find, signals the shift to a 'third generation' thinking on minipublics, which is critical in today's context where minipublics are increasingly used not just as governance innovations but as long-term institutional remedies to crisis of democracy. To explain this point, we devote the next sections to briefly sketch the evolution of the scholarly research on minipublics, and then characterise what we observe to be the emerging way of thinking about these forums, including Lafont's intervention. While we speak of generations of minipublics thinking, we do not mean to imply that the scholarship and practice of minipublics are linear. Nor do wish to box people to particular generations. We use the term generations as an analytical shorthand to demonstrate the shifts in thinking about micro-deliberative forums over the years and locate these shifts within political contexts in which they are made.

\section{The first generation of minipublics}

The first generation of minipublics is focused on achieving high quality deliberation by eliminating communicative distortions in the public sphere. They are pitched as a representation of a 'counterfactual' public opinion or what lay citizens would think had they been given the opportunity to listen, weigh evidence, deliberate across difference, and reflect on their views. With some exceptions, these minipublics are one-shot events. They are organised by public authorities, sometimes in collaboration with researchers. They serve a consultative function to provide input to policymaking (Sintomer 2018). Citizen juries (Crosby \& Nethercut 2004), planning cells (Dienel 2002) and deliberative polls (Fishkin 2011) are some examples.

The scholarship on first generation minipublics presents a two-fold narrative. First, researchers provide evidence that under the right conditions, citizens are capable of deliberating and making sound judgments (for an overview see Bächtiger \& Parkinson 2019). One of the very first minipublics, the citizens' jury, aimed at creating a process to enhance reason and empathy among citizens and to investigate whether 'a microcosm of the public could effectively deal with complex issues' (Crosby $\&$ Nethercut 2004: 112). How minipublics work internally is the focus of scholarly investigation, manifest with the development of indicators that track how citizens process new information, the kinds of citizens who transform their preferences or views on an issue, and patterns of speech that deepen or obstruct deliberation. While systematising and comparing cross-national data on the deliberative quality of minipublics is still a work-in-progress, there is a wealth of single and comparative case studies that establish the extent to which minipublics can promote empathy, learning, social cohesion and political efficacy, among others.

The second narrative locates the role of minipublics within governance systems (Bingham et al. 2005; Fung
2006; Fung \& Wright 2003; Papadopoulos \& Warin 2007; Rowe \& Frewer 2000). Minipublics are viewed as tools to improve the quality of policymaking. As Archon Fung points out, these developments took place 'in a political moment of seeming stability ... for liberal democratic institutions.' It was a time when deliberative democrats took for granted the 'normal' functioning of representative governments in western liberal democracies, which alternate between centre left and centre right parties (Fung 2020: 75). Minipublics are viewed as attempts to make democracies more responsive to public reason. Among the classic examples are the Danish consensus conferences which provided considered citizen input on complex technological issues (Hendriks 2005) and German planning cells which were consulted on urban issues (Dienel 1999). Proponents of the first generation of minipublics aspire for these forums to be incorporated in mainstream policy making, though how to standardise the design and implementation of these forums on a large scale remains an open question (Sintomer 2018).

Beyond practical questions of broadening the reach of minipublics, however, are profound questions about these forums' roles in democratic deepening. Given the top-down character of minipublics, there are scepticisms about their conservative character (Hammond 2020). There is a tenuous link between minipublics' mandate to generate considered public opinion to calls for social justice and subversion of power structures particularly in market societies (Pateman 2012). In terms of scholarship, one consequence of focusing on assessing the internal quality of minipublics is the neglect of their relationship with mass democracy (Chambers 2009). The cloistered character of minipublics is both a blessing and a curse. While it can serve as a counterfactual space where citizen deliberation can thrive without the distortions in the public sphere, it is disconnected with the messy and contentious dynamics of 'real world' public debates. How can reasons offered inside these forums be persuasive outside it (Parkinson 2003, 2006a, see also Lafont 2015)? What use are high quality deliberations in minipublics if their contributions to the democratic system - not just the governance system - is severely constrained (Rummens 2016)?

\section{The second generation of minipublics}

The second generation of minipublic thinking responds to these weaknesses by conceptualising minipublics as 'nested' within democratic systems. This, we argue, is where minipublics research mostly stands today. Scholarly attention is focused on identifying the political uses of minipublics beyond serving as tools for governance. There is increasing emphasis on how minipublics contribute to wider public deliberations and decision-making, as in the case of the Irish Citizens' Assembly on abortion and samesex marriage (see Farrell \& Suiter 2019) or the French Citizens' Convention on Climate Change (CESE 2020). That both of these examples are tied to referendums highlight the agenda-setting and discourse-shaping power of minipublics in the public sphere. Others demonstrate 
how minipublics can be - and some of them are already - connected to existing institutions of representative decision-making (Hendriks 2016; Setälä 2017). Others, meanwhile, advocate new institutions of democratic deliberation, including the creation of a sortition chamber (Gastil \& Wright 2019).

The call for nesting minipublics in democratic systems is partly driven by the demand for democratic reforms during a period where traditional institutions of representative democracy are suffering from legitimacy deficits. Minipublics are expected to bridge the disconnect between people and power. It does so through hybrid models of citizen assemblies where ordinary citizens deliberate with politicians as in the Irish case or through reforms that oblige elected members of parliament to respond to the agenda set by a sortition chamber as in the case of Ostbelgien. The legacy of the first generation remains as far as minipublics are still designed to be 'more perfect public spheres' to use Fung's (2003) term, but these forums are no longer protected from the imperfections of democratic systems. The British Columbia Citizens' Assembly, for example, asked assembly members to engage in public hearings and hear from union representatives, community organisations, and political parties. Far from being insulated from notorious campaign tactics in the public sphere, Assembly members experienced how seasoned political actors amplified the same message on voting reform in public hearings and online forums (Lang 2007). This model is far from the ideal counterfactual of deliberation that first generation minipublics envisioned.

Nesting minipublics in democratic systems made up for some of the critiques in first generation thinking but there remain unresolved issues. First, Pateman's critique stands. To what extent can minipublics disturb power inequalities in existing institutions to forge a participatory society (see also Parthasarathy et al. 2019)? We recognise that linking minipublics to wider processes of democratic decisionmaking empowers an institution that has the most diverse demographic profile than any institution of representative democracy. Yet, this improvement neither fosters largescale democratisation nor prevents the alienation of the wider citizenry to the minipublic. Minipublics involve a small proportion of the whole citizenry to change the distribution of power. Minipublics may have an educative function. Their participants may feel a greater sense of political efficacy. But these benefits do not necessarily diffuse to the wider society. 'Empowering the few is hardly ever a way of empowering the many,' as Lafont puts it (Lafont 2019: 111).

Second, minipublics are also not immune from the critique of representative institutions as being detached from the wider citizenry. A minipublic's output that does not seek to persuade the whole citizenry is a democratic shortcut, as Lafont puts it, as far as it requires citizens who are not part of the minipublic to blindly defer to the decision of others (Lafont 2019). It challenges the ideal of self-government where citizens can see themselves as the authors and subjects of the law or policy. There is a risk that citizens cannot identify with a policy shaped by a minipublic since its participants are not just like ordinary citizens anymore and instead have become citizen-experts (Parkinson 2006b: 82). In sum, second generation thinking still upholds the idea that minipublics quasi-automatically strengthen democracy, and the main focus is thus on amending potential deficits of equality, emancipation, or consequentiality.

\section{The third generation of minipublics}

Lafont's work, based on our reading, opens the theory and practice of deliberative democracy to third generation thinking on minipublics. This involves a critical albeit sympathetic understanding of the political uses of these forums in democratic systems. Lafont $(2017,2019)$ has sketched some pathways for a participatory re-orientation of minipublics. Minipublics do not automatically deepen democracies, nor do they necessarily avert the crisis of democracy. Instead, for Lafont, minipublics fulfil a participatory function when they: (1) contest the majority opinion of the population and thus send a signal to the population of how an informed citizenry would think and decide, prompting the population to re-think their opinions; (2) when they play a vigilant role by alerting the public that popular opinions are ignored by political authorities; or (3) when they anticipate issues that are ignored in the wider public. But at the same time, a participatory re-orientation of minipublics must be reconciled - or balanced - with the fact that complex governance systems must rely upon divisions of cognitive labour whereby most citizens lack the time and resources to know much about the merits of policy debates (Gastil \& Warren 2015). This requires a simultaneous and dedicated focus on minipublics as information shortcuts (in connection with trust-based uptake). While Lafont's participatory conception of minipublics is fairly minimal and neither means that people spend 'too many evenings' in active participation nor abstain from taking heuristics and cues in general, she nonetheless thinks that uptake from minipublics cannot be 'blind' since citizens will never know whether recommendations or decisions made by them will be aligned with their own interests, values and policy objectives (Lafont 2019: 170). Uptake of minipublics' recommendations are different in the case of our own favoured party or interest group, since in this constellation there is a basic alignment with our interests, values and policy objectives: here we could take the shortcut route without losing democratic authorship. Consequently, we would always need to engage with minipublics via reasons rather than via pure recommendations.

Future empirical research will need to tackle whether minipublics best operate on a fully-fledged shortcut track or a participatory track (Lafont 2019). A shortcut track is one where minipublics can be trusted to provide recommendations on behalf of the population by virtue of their composition, internal quality of deliberation, and their institutionalisation. A participatory track, meanwhile, is one where arguments tested or clarified by minipublics affect discussions in the public sphere. Here, recommendations of minipublics are less relevant than the reasons behind them (Niemeyer 2014; Parkinson 
2020). A participatory track further opens questions on the ways in which minipublics can be institutionalised in such a way that a feedback loop or recursive dialogue between minipublics and wider publics can be forged. It also enquires into different ways in which citizens can serve as authors of laws and policies to which they are subject beyond minipublics.

While the special issue takes a prime focus on Lafont's foundational critique, a third-generation journey does not end here. Lafont's work also serves as reminder to take problem-based or goal-oriented approach to minipublics seriously (Bächtiger \& Parkinson 2019; Beauvais \& Warren 2019; Warren 2017). A problembased or goal-oriented view starts from the idea that a viable future for minipublics is not only about amending their apparent deficits such as a lack of visibility, consequentiality, legitimacy or a lack of emancipatory orientation. It is also about re-thinking their broader functionality in a democratic system. A problem-based or goal-oriented approach starts from the assumption that a well-functioning democratic system will require different democratic practices and institutions in order to fulfil essential democratic functions, namely empowered inclusion, collective will-formation and collective decision-making (Warren 2017). But no democratic practice - neither deliberation nor voting - can fulfil all democratic functions. Hence, a problembased or goal-oriented approach breaks with the concept of the 'minipublic approach' arguing that more citizen involvement via minipublics will enhance and strengthen democratic governance, as is still evident in the second generation. Rather, minipublics - are institutional means for specific ends. If these ends can be reached more efficiently via other institutional pathways, then we might decide to choose these other means rather than using minipublics. Minipublics, in other words, are not 'necessary' for democracy. As Lafont suggests,

what is necessary is effective inclusion of everyone in the process of opinion- and will-formation ... but how each society gets there (how it manages to secure effective rights to political contestation for all citizens) depends on contingent, historical circumstances and path dependencies. Different institutional solutions may be best suited for different societies. $^{2}$

Lafont's participatory approach has affinities with such a problem-based or goal-oriented approach: not only does it re-think the conditions under which minipublics can fulfil a proper democratic role in a democratic system, but it is also open to a variety of institutional means to achieve specific democratic roles as becomes evident in her stress on judicial review to fulfil a participatory function. ${ }^{3}$ Jonathan Kuyper and Fabio Wolkenstein (2019), for instance have argued that minipublics should have strong decision-making powers if the representative system is not responsive to citizen concerns. Conversely, if the representative system is basically responsive, then deliberative forums should only have consultative functions. As such, the answer to the question whether minipublics should have the authority to make binding decisions is a contingent one. At the extreme, a problembased approach can even think that democratic systems can do without minipublics. For instance, if the goal is more feedback to politics, then a fully-fledged direct democratic system like Switzerland might provide a sufficient route to achieve this goal. Politicians learn from both negative and positive votes in referendums, through a recursive dialogue with their constituents (El-Wakil 2020). Over time, this system has led to relatively good anticipations of what the 'median voter' may desire, rendering additional input from deliberative minipublics less necessary (Bächtiger \& Beste 2017). Rather than trying to fix or amend the (democratic) operation of minipublics, a problem-based approach asks what 'added value' they provide for democratic systems and under what contexts. Clearly, in the age of serial crisis (Curato et al. 2020) as well as in the eyes of many citizens worldwide, deficits in inclusiveness and responsiveness of democratic systems seem endemic, which creates a clear demand for more citizen involvement, and minipublic represent a premier route to achieve this goal. As such, both first generation experimentalism - focusing on how to make minipublics work (and work better) in practice - and second generation 'nesting' an institutionalization attempt - focusing on how to enhance their consequentiality in the political system - are crucial predicaments to fulfil such demands. But it is also possible to imagine a flourishing deliberative democracy without minipublics. There are many ways in which societies can correct distortions in political communication that allows the process of collective will formation to be based on an inclusive exchange of other-regarding reasons and considerations. This special issue, we hope, provokes further discussion of the third generation thinking about minipublics.

\section{The Special Issue}

The genesis of this special issue is in the Author Meets Critics panel of the American Political Science Association Annual Meeting in Washington DC in 2019. In this lively panel, Lafont engaged with some of the book's interlocutors, which, we found, was a valuable exercise to sharpen our thinking about issues on minipublics and deliberative democracy, legitimacy and blind deference, among other issues. We invited her interlocutors to further develop these critiques in this special issue. We also broadened the conversation to include empirical pieces that further ground Lafont's theoretical work. Finally, Lafont dedicated the book to Jürgen Habermas, and so we took our chances and invited him to respond to Lafont's work. He willingly obliged.

Our line up therefore begins with Habermas's philosophical critique in which he first reflects on Lafont's criticism of radical pluralist and expertocratic conceptions of democracy, and on her distinction of deliberation's two functions, namely the epistemic and the socially integrative function. Habermas criticises Lafont's interpretation of the epistemic function as oriented towards truth statements, which risk conflating 
normative statements with factual ones. He also provides a systematic consideration of the reflexive stage of democratic constitutional foundation in order to complement Lafont's principle of self-government.

Following Habermas's interventions are pieces by Jane Mansbridge, Robert E. Goodin and André Bächtiger and Saskia Goldberg which interrogate a critical concept in Lafont's book - blind deference to the decisions of minipublics. Mansbridge starts with reframing the binary dimension of legitimacy and blind deference. She argues that since legitimacy is aspirational and derives from different sources (e.g. quality of the feedback loop, reflective endorsement, active participation), it implies that a law's legitimacy is always partial and is a matter of degree. Accordingly, she suggests a spectrum of deference, in which citizens can decide to defer responsibility to some institutions or to insulate others beyond the citizenry's direct control. Relatedly, Goodin reflects on the degree of gradations between full endorsement and blind deference. He also argues that full endorsement is an ideal and that blind deference is not the only alternative. Instead, citizens need to endorse the process by which laws are enacted - and not their substance - and they may defer to others as long as they exercise their own critical judgement when doing so. Lastly, Bächtiger and Goldberg put forward the idea of 'semi-blind deference' and updates the minipublics' trust-based use to an 'enhanced shortcuts approach' (MacKenzie \& Warren 2012; Warren $\&$ Gastil 2015). They argue that minipublics could send signals to citizens for updating their opinions on an issue by searching for further information and engaging with arguments. Mark Warren's article, at the end of the special issue, also suggests a conception of 'democratic shortcuts' which envisions the extension and realization of democratic self-government through a warranted trust-based principal-agent relationship. Citizens suspend their judgement because they trust that their interests and values align with those of their agents.

The special issue then transitions to ground Lafont's work in empirical research. James Pow, Lisa van Dijk and Sofie Marien address the question of minipublics on a shortcut track by investigating what a minipublic's legitimacy looks like in practice and why would nonparticipants trust it. They surveyed citizens in Northern Ireland about a minipublic on the polity's constitution and found that non-participants support the minipublic to the extent that they perceive its participants to be 'like them'. Based on these results, they argue that minipublics could aid conventional representative democracy to bridge the gap between politicians and the citizenry.

The next two contributions discuss Lafont's conception of minipublics' empowerment, and whether being the second-best option of a shortcut track is enough, and how a first-best option of a participatory track would empirically look like. In the first one, James Fishkin draws on his experience on deliberative polls to propose a counter argument to Lafont's rationale for not empowering minipublics. He argues that empowered minipublics do not per se imply the citizenry's blind deference, as long as the minipublic is well organized and its considered opinions help decision-makers to avoid adopting a law that would become illegitimate when the raw public opinion becomes enlightened. Furthermore, Fishkin directly addresses Lafont's criticisms of his 'second-best strategy'. Relying on the zero-sum game trilemma between political equality, mass participation and deliberation, he argues that Lafont's first best strategy does not solve the trilemma as it does not feature mass participation and rests on the theoretical right of all citizens to make a lawsuit. Instead, Fishkin restates the potential of a Deliberation Day (Ackerman \& Fishkin 2004) to realize the three values simultaneously. Meanwhile, Ronald van Crombrugge takes Lafont's challenge of implementing a participatory use of minipublics, but also alerts us about the challenges for doing so. He conducts a case study of the Citizens' Assembly Bill introduced by the Green Party in the Flemish Regional Parliament in Belgium. His analysis provides an account of how a minipublic could be institutionalized following Lafont's precepts and also describes which practical challenges such institutionalization poses.

Finally, the special issue returns to theoretical critiques of Lafont's book. Simone Chambers takes up Lafont's idea of a judicial review, by which citizens can challenge any laws in constitutional courts. She disagrees with this mechanism because it involves that only citizens 'in robes' can ask to revise a law and fails to separate the episodic higher law-making of constitutional politics from the ordinary law-making of everyday politics. Meanwhile, Mark Warren and Tetsuki Tamura question the statecentric conception of democracy that Lafont adopts in her book. They both suggest broadening the conception of democracy beyond the state structure. Tamura criticizes Lafont's state-centric approach of democracy and reflects on the extension of her normative project of democratic self-government to other sites of the system, such as the workplace or the family. He then proposes a new conception of deliberative democracy which relies on a 'pluralized understanding of both self-government and sites of democracy'. In the same vein, Warren asserts that in complex mass societies, citizens can participate in multiple ways which Lafont does not discuss. He suggests the principle of 'all affected', which contends that someone affected by any collectivity (not only the state but also the market for instance) should have the standing and capacity to influence it. His conclusion calls for the extension of the participatory deliberative democracy so that it matches the emerging spaces of policies. The Special Issue concludes with Lafont's response, in which she directly and genuinely engages with each commentary piece of the special issue.

\section{Conclusions}

Lafont's book marks a milestone in the field of deliberative democracy. Her participatory conception of deliberative democracy reconciles deliberative and participatory models of democracy and provides a comprehensive theoretical and normative framework on how deliberative democracy should unfold in today's complex societies. By the same token, it represents 
an opportunity to advance the research agenda on minipublics and deliberative democracy. This special issue brings together a series of pieces that critically think through Lafont's work but also develop it. In this introduction to the Special Issue we have also advanced a 'third generation' thinking about minipublics which draws on Lafont's work but simultaneously considers a fully-fledged problem- or goal-oriented approach. The third generation breaks with the 'minipublic approach' of its predecessors and invites a conversation on whether minipublics per se are necessary for a wellfunctioning democratic system - a point that Lafont strongly supports. ${ }^{4}$ Minipublics, as the third generation thinking goes, should be considered as institutional means to fulfil specific democratic functions and not as institutional ends for deliberative democracy. Surely, our intention is not to dismiss previous work and determine how future research on and practice of minipublics should unfold. Nor do we think that amending the working of minipublics - as we find it in the first and second generation - is a futile enterprise. Quite the contrary, minipublics that function well and are strongly connected to policymaking arenas can be an asset for re-vitalizing our democracies. Our only intention here is to open the discussion and stimulate the reflection on how minipublics - or other institutional means - can effectively and efficiently improve the democratic and deliberative quality of our political systems.

\section{Notes}

${ }^{1}$ The Varieties of Democracy project identified 'media, hearings, panels, and other deliberative bodies' as institutions of deliberative democracy though the precise ways of operationalising the deliberative quality of these bodies remain contentious (Coppedge et al., 2011).

2 Lafont, personal correspondence.

${ }^{3}$ We thank Lafont for helping us clarify this point.

${ }^{4}$ Lafont, personal correspondence.

\section{Competing Interests}

The authors have no competing interests to declare.

\section{References}

Ackerman, B. A., \& Fishkin, J. S. (2004). Deliberation day. New Haven, CT: Yale University Press.

Bächtiger, A., \& Parkinson, J. (2019). Mapping and measuring deliberation: Towards a new deliberative quality. Oxford: Oxford University Press. DOI: https:// doi.org/10.1093/oso/9780199672196.001.0001

Beauvais, E., \& Warren, M. E. (2019). What can deliberative mini-publics contribute to democratic systems? European Journal of Political Research, 58(3), 893-914. DOI: https://doi.org/10.1111/1475-6765.12303

Bingham, L. B., Nabatchi, T., \& O'Leary, R. (2005). The new governance: Practices and processes for stakeholder and citizen participation in the work of government. Public Administration Review, 65(5), 547-558. DOI: https://doi.org/10.1111/j.1540-6210. 2005.00482.x
CESE. (2020). Rapport de la Convention Citoyenne pour le Climat. Centre Économique Social et Environnemental Paris.

Chambers, S. (2009). Rhetoric and the public sphere: Has deliberative democracy abandoned mass democracy? Political Theory, 37(3), 323-350. DOI: https://doi. org/10.1177/0090591709332336

Coppedge, M., et al. (2011). Conceptualizing and measuring democracy: A new approach. Perspectives on Politics, 247-267. DOI: https://doi.org/10.1017/ S1537592711000880

Crosby, N., \& Nethercut, D. (2004). Citizen juries. In J. Gastil and P. Levine (Eds.) The Deliberative Democracy Handbook: Strategies for effective civic engagement in the twenty-first century (pp. 111-119). San Francisco, CA: Jossey-Bass.

Curato, N., Hammond, M., \& Min, J. B. (2019). Power in deliberative democracy. New York: Palgrave Macmillan. DOI: https://doi.org/10.1007/978-3-319-95534-6

Curato, N., Sass, J., Ercan, S., \& Niemeyer, S. (2020). Deliberative democracy in the age of serial crisis. International Political Science Review. DOI: https://doi. org/10.1177/0192512120941882

Dienel, P. C. (1999). Planning cells: The German experience. In U. Khan (Ed.) Participation beyond the ballot box: European case studies in state-citizen political dialogue (pp. 81-94). London: Routledge. DOI: https://doi.org/10.4324/9780203982204

Dienel, P. C. (2002). Die Planungszelle. Berlin: Springer. DOI: https://doi.org/10.1007/978-3-322-80842-4

El-Wakil, A. (2020). Supporting deliberative systems with initiatives and referendums. Journal of Deliberative Democracy, 16(1), 37-45. DOI: https://doi. org/10.16997/jdd.403

Farrell, D. M., \& Suiter, J. (2019). Reimagining democracy: Lessons in deliberative democracy from the Irish front line. Ithaca, NY: Cornell University Press. DOI: https:// doi.org/10.7591/9781501749346

Fishkin, J. S. (2011). When the people speak: Deliberative democracy and public consultation. Oxford: Oxford University Press. DOI: https://doi.org/10.1093/acpro f:osobl/9780199604432.001.0001

Font, J., Smith, G., Galais, C., \& Alarcon, P. (2018). Cherry-picking participation: Explaining the fate of proposals from participatory processes. European Journal of Political Research, 57(3), 615-636. DOI: https://doi.org/10.1111/1475-6765.12248

Fung, A. (2003). Survey article: Recipes for public spheres: Eight institutional design choices and their consequences. Journal of Political Philosophy, 11(3), 338-367. DOI: https://doi.org/10.1111/14679760.00181

Fung, A. (2006). Varieties of participation in complex governance. Public Administration Review, 66(s1), 66-75. DOI: https://doi.org/10.1111/j.15406210.2006.00667.x

Fung, A. (2020). Afterword: Does deliberative democracy have a role in our time of political crisis? Journal of Deliberative Democracy, 16(2). DOI: https://doi. org/10.16997/jdd.407 
Fung, A., \& Wright, E. O. (2003). Deepening democracy: Institutional innovations in empowered participatory governance. London: Verso.

Gastil, J., \& Wright, E. O. (2019). Legislature by lot: Transformative designs for deliberative governance. London: Verso.

Hammond, M. (2019). Deliberative democracy as a critical theory. Critical Review of International Social and Political Philosophy, 22(7), 787-808. DOI: https:// doi.org/10.1080/13698230.2018.1438333

Hammond, M. (2020). Democratic innovations after the post-democratic turn: Between activation and empowerment. Critical Policy Studies, 1-18. DOI: https://doi.org/10.1080/19460171.2020.1733629

Hendriks, C. M. (2005). Consensus conferences and planning cells: Lay citizen deliberations. In J. Gastil and P. Levine (Eds.) The Deliberative Democracy Handbook: Strategies for effective civic engagement in the twenty-first century (pp. 80-110). San Francisco, CA: Jossey-Bass.

Hendriks, C. M. (2016). Coupling citizens and elites in deliberative systems: The role of institutional design. European Journal of Political Research, 55(1), 43-60. DOI: https://doi.org/10.1111/1475-6765.12123

Hennig, B. (2017). The end of politicians. London: Unbound Publishing.

Hoppe, R. (2011). Institutional constraints and practical problems in deliberative and participatory policy making. Policy \& Politics, 39(2), 163-186. DOI: https:// doi.org/10.1332/030557310X519650

Kuyper, J. W., \& Wolkenstein, F. (2019). Complementing and correcting representative institutions: When and how to use mini-publics. European Journal of Political Research, 58(2), 656-675. DOI: https://doi. org/10.1111/1475-6765.12306

Lafont, C. (2015). Deliberation, participation, and democratic legitimacy: Should deliberative mini-publics shape public policy? Journal of Political Philosophy, 23(1), 40-63. DOI: https://doi.org/10.1111/jopp.12031

Lafont, C. (2017). Can democracy be deliberative \& participatory? The democratic case for political uses of mini-publics. Daedalus, 146(3), 85-105. DOI: https:// doi.org/10.1162/DAED_a_00449

Lafont, C. (2019). Democracy without shortcuts: A participatory conception of deliberative democracy. Oxford: Oxford University Press. DOI: https://doi. org/10.1093/oso/9780198848189.001.0001

Lang, A. (2007). But is it for real? The British Columbia citizens' assembly as a model of state-sponsored citizen empowerment. Politics \& Society, 35(1), 35-70. DOI: https://doi.org/10.1177/0032329206297147

MacKenzie, M. K., \& Warren, M. E. (2012). Two trustbased uses of minipublics in democratic systems. In $\mathrm{K}$. Grönlund, A. Bächtiger \& M. Setälä (Eds.) Deliberative systems: Deliberative democracy at the large scale (pp. 95-124). Colchester: ECPR Press. DOI: https://doi. org/10.1017/CBO9781139178914.006

Niemeyer, S. (2014). Scaling up deliberation to mass publics: Harnessing mini-publics in a deliberative system. In K. Grönlund, A. Bächtiger \& M. Setälä (Eds.) Deliberative mini-publics: involving citizens in the democratic process (pp. 177-202). Colchester: ECPR Press.

Niessen, C., \& Reuchamps, M. (2019). Designing a permanent deliberative citizens' assembly. Centre for Deliberative Democracy and Global Governance Working Paper Series, 6.

OECD. (2020). Innovative Citizen Participation and New Democratic Institutions: Catching the Deliberative Wave. Paris: OECD Publishing. DOI: https://doi. org/10.1787/339306da-en

Papadopoulos, Y., \& Warin, P. (2007). Are innovative, participatory and deliberative procedures in policy making democratic and effective? European Journal of Political Research, 46(4), 445-472. DOI: https://doi. org/10.1111/j.1475-6765.2007.00696.x

Parkinson, J. (2003). Legitimacy problems in deliberative democracy. Political Studies, 51(1), 180-196. DOI: https://doi.org/10.1017/S0007123406000093

Parkinson, J. (2006a). Rickety bridges: Using the media in deliberative democracy. British Journal of Political Science, 36(1), 175-183. DOI: https://doi. org/10.1111/1467-9248.00419

Parkinson, J. (2006b). Deliberating in the real world: Problems of legitimacy in deliberative democracy. Oxford: Oxford University Press.

Parkinson, J. (2020). The roles of referendums in deliberative systems. Representation, 1-16. DOI: https://doi.org/10.1080/00344893.2020.1718195

Pateman, C. (2012). Participatory democracy revisited. Perspectives on Politics, 10(1), 7-19. DOI: https://doi. org/10.1017/S1537592711004877

Pogrebinschi, T., \& Ryan, M. (2018). Moving beyond input legitimacy: When do democratic innovations affect policy making? European Journal of Political Research, 57(1), 135-152. DOI: https://doi.org/10.1111/14756765.12219

Reuchamps, M. (2020). Belgium's experiment in permanent forms of deliberative democracy. ConstitutionNet, 1, retrieved from http:// constitutionnet.org/news/belgiums-experimentpermanent-forms-deliberative-democracy

Rowe, G., \& Frewer, L. J. (2000). Public participation methods: A framework for evaluation. Science, Technology, \& Human Values, 25(1), 3-29. DOI: https:// doi.org/10.1177/016224390002500101

Rummens, S. (2016). Legitimacy without visibility? On the role of mini-publics in the democratic system. In M. Reuchamps and J. Suiter (Eds.), Constitutional Deliberative Democracy in Europe (pp. 129-46). Colchester: ECPR Press.

Setälä, M. (2017). Connecting deliberative mini-publics to representative decision making. European Journal of Political Research, 56(4), 846-863. DOI: https://doi. org/10.1111/1475-6765.12207

Sintomer, Y. (2018). From deliberative to radical democracy? Sortition and politics in the twentyfirst century. Politics \& Society, 46(3), 337-357. DOI: https://doi.org/10.1177/0032329218789888

Van Reybrouck, D. (2016). Against elections: The case for democracy. London: Random House. 
Vrydagh, J. (2019). Disentangling the policy impact of mini-publics: A case study of the citizens' panel 'make your Brussels mobility'. Paper presented at ECPR General Conference 2019, Wroclaw, Poland.

Warren, M. E. (2017). A problem-based approach to democratic theory. American Political Science Review,
111(01), 39-53. DOI: https://doi.org/10.1017/ S0003055416000605

Warren, M. E., \& Gastil, J. (2015). Can deliberative minipublics address the cognitive challenges of democratic citizenship? The Journal of Politics, 77(2), 562-574. DOI: https://doi.org/10.1086/680078
How to cite this article: Curato, N., Vrydagh, J., \& Bächtiger, A. (2020). Democracy without Shortcuts: Introduction to the Special
Issue. Journal of Deliberative Democracy, 16(2), pp.1-9. DOl: https://doi.org/10.16997/jdd.413 Submitted: 12 August $2020 \quad$ Accepted: 13 August $2020 \quad$ Published: 14 October 2020

Copyright: (c) 2020 The Author(s). This is an open-access article distributed under the terms of the Creative Commons Attribution 4.0 International License (CC-BY 4.0), which permits unrestricted use, distribution, and reproduction in any medium, provided the original author and source are credited. See http://creativecommons.org/licenses/by/4.0/.

Journal of Deliberative Democracy is a peer-reviewed open access journal published by University of Westminster Press. 